\title{
REMOVAL OF 2,4-DICHLOROPHENOL BY SIMULTANEOUS ADSORPTION AND BIODEGRADATION (SAB) USING LOW COST ADSORBENT
}

\author{
ULLHYAN A. ${ }^{*}$ \\ GHOSH U.K.
}

Indian Institute of Technology Roorkee

Department of Paper Technology

Saharanpur Campus

Saharanpur - 247001, India
Received: 07/10/2013

Accepted: 30/04/2014

Available online: 06/05/2014 *to whom all correspondence should be addressed: e-mail: anupadpt@iitr.ernet.in

\section{ABSTRACT}

This study was aimed to investigate the use of Mustard stalk as a cheap, eco-friendly adsorbent with support matrix for the immobilization of microbial cell and for subsequent removal of 2,4-dichlrophenol(2,4-DCP) from waste water. A comparative batch study between adsorption as well as simultaneous adsorption and biodegradation (SAB) of 2,4-DCP by mustard stalk immobilized Pseudomonas putida MTCC1194 have been studied in conical flask having concentration ranges of 2,4-DCP from 100 to $1000 \mathrm{mg} \mathrm{l}^{-1}$ with adsorbent dose range 1 to $12 \mathrm{~g} \mathrm{l}^{-1}$ at $\mathrm{pH}$ range 2 to 9 and temperature range $28^{\circ} \mathrm{C}$ to $35^{\circ} \mathrm{C}$, placed in an orbital shaker. The results of the batch studies showed that simultaneous adsorption and biodegradation (SAB) shows the maximum percent (91\%) removal of 2,4DCP as compared to simple adsorption (86 \%) at optimum temperature $32{ }^{\circ} \mathrm{C}$ of adsorbent dose $10 \mathrm{~g} \mathrm{I}^{-1}$, and $\mathrm{pH} 6$ with MSAC having particle size $0.24 \mathrm{~mm}$. The equilibrium data for 2,4-DCP degradation sorbent systems were well fitted with Langmuir isotherm.

Keywords: 2,4-dichlorophenol, SAB, AC, Pseudomonas putida, Adsorption, Mustard stalk.

\section{Introduction}

A variety of chemicals are commercially produced and newly synthesized every year. During their manufacture and use, these chemicals are often discharged into environment. Many of them degrade slowly and exert toxic effect on plants and animals, thus causing large scale environmental degradation (Annadurai et al., 2007). Chlororinated phenolic compounds present in industrial waste water such as polymeric resins, petroleum refining, and pesticides are difficult to remove, highly toxic and difficult to degrade biologically. The chronic toxic effects of chlororinated phenolic compounds reported in humans including vomiting, difficulty in swallowing, anorexia, liver and kidney damage, headache, fainting and other mental disturbance. The Ministry of Environment and Forest (MOEF), Government of India and EPA, USA, have listed phenolic and phenolic compounds on priority-pollutants lists. The MOEF has set a maximum concentration level of $1.0 \mathrm{mg} \mathrm{l}^{-1}$ of phenolic compound in the industrial effluents for the safe discharge into the surface water, the WHO recommends the permissible phenolic concentration of $0.001 \mathrm{mg} \mathrm{l}^{-1}$ in potable water. Thus because of toxicity of chlororinated phenolic compounds many treatment processes have been applied for the removal of them from waste water. Some of these processes include: adsorption (Zhao et al., 2010), photo-fenten degradation (Parida and Prahan, 2010), photocatalytic degradation (Devipriya and Yesodharan, 2010) and biodegradation (Agarry and Solomon, 
2008). Combined methods like biochemical, electrochemical, physicochemical or simultaneous adsorption and biodegradation is nowadays gaining importance. Simultaneous adsorption and biodegradation increases the life of adsorbent, as biofilm on adsorbent degrade the adsorbate (Mondal and Balomajumder, 2007; Wang et al., 2000).

Agricultural by-products have proved to be promising raw materials for the production of ACs They can be used for the production of AC with a high adsorption capacity, considerable mechanical strength, and low ash content and their availability at a low price. (Mahadevaswamy et al.,1997 and Chen et al., 2011). Some of the agricultural waste products that has been developed as adsorbents include, orange and banana peels (Annadurai et al., 2002), spent tea leaves (Hameed, 2009), tamarind fruit shell (Popuri et al., 2007), soya bean hull (Ahmedna et al., 2000), cotton seed hull and corn cobs (Reddad et al., 2002), rubber fruit pericarp (Agarry and Owabor, 2005).

In this research paper, a detailed study on sorption potential of an abundantly available agricultural byproduct Mustard stalk as non-conventional adsorbent. Mustard stalk activated carbon used as support matrix for Pseudomonas putida MTCC 1194 immobilization to remove 2,4-dichlorophenol from waste water. The effects of adsorbent dose, contact time, initial phenol concentration, $\mathrm{pH}$ and temperature on removal of 2,4-dichlorophenol by simultaneous adsorption-biodegradation(SAB) were studied.

\section{Materials and methods}

All the reagents and 2,4-dichlorophenol were procured from by Hi-Media Company make. An accurately weighed quantity of the 2,4-dichlorophenol was dissolved in double-distilled water to prepare a stock solution (1000 mg l-1). The desired concentration range 100-1000 $\mathrm{mg} \mathrm{l}^{-1}$ were obtained by successive dilutions with double-distilled water. Pseudomonas putida MTCC 1194 was obtained from Institute of Microbial Technology, Chandigarh, India. The composition of the basal salt medium (BSM) used in this experiment as the growth medium contained $1.5 \mathrm{~g} \mathrm{l}^{-1} \mathrm{~K}_{2} \mathrm{HPO}_{4}, 0.5 \mathrm{~g} \mathrm{I}^{-1} \mathrm{KH}_{2} \mathrm{PO}_{4}, 0.5 \mathrm{~g} \mathrm{l}^{-1}\left(\mathrm{NH}_{4}\right)_{3} \mathrm{PO}_{4}$, $0.5 \mathrm{~g} \mathrm{l}^{-1} \mathrm{NaCl}, 3 \mathrm{~g} \mathrm{l}^{-1} \mathrm{Na}_{2} \mathrm{SO}_{4}, 2 \mathrm{~g} \mathrm{l}^{-1}$ Yeast extract, $0.5 \mathrm{~g} \mathrm{l}^{-1}$ Glucose, $0.002 \mathrm{~g} \mathrm{l}^{-1} \mathrm{FeSO}_{4}$ and $0.002 \mathrm{~g} \mathrm{l}^{-1} \mathrm{CaCl}_{2}$. Activated carbon prepared from chemically treated mustard stalk, the procedure mention by Madhava et al. 2006, having surface area $129 \mathrm{~m}^{2} \mathrm{~g}^{-1}$ was used as adsorbent and solid support matrix for microbial cell immobilization.

\subsection{Acclimatization}

The acclimatization of Pseudomonas putida (MTCC1194) in phenolic environment was performed as follows: The revived culture were first grown in basal salt medium with glucose as sole carbon source. The culture were acclimatized to phenol by exposing the cultures in a series of shake flasks ( $250 \mathrm{ml})$, After $48 \mathrm{hr}$, significant bacterial growth was observed in the flask and the turned milky. Appropriate quantity of stock solution of 2,4-DCP was added into the flask containing BSM to get a concentration of $10 \mathrm{mg} \mathrm{l}^{-1}$ of 2,4-DCP It was kept aside, initially growth of Pseudomonas putida was inhibited and degradation of 2,4-DCP started after $5 \mathrm{hr}$. Thereafter, the 2,4-DCP was periodically added in increments of $10 \mathrm{mg} \mathrm{l}^{-1}$ in a series of $250 \mathrm{ml}$ flasks till the 2,4-DCP concentration in the growth media reached $1000 \mathrm{mg} \mathrm{l}^{-1}$. For inoculums, a further sub culturing was done and all the inoculums transfers were done in exponential phase.

\section{Experimental procedure}

For Adsorption studies concentration ranges of 2,4-DCP from 100 to $1000 \mathrm{mg} \mathrm{l}^{-1}$ were kept in the conical flasks along with adsorbent dose range 1 to $12 \mathrm{~g} \mathrm{I}^{-1}$ at pH range 2 to 9 having temperature range $25^{\circ} \mathrm{C}$ to $38^{\circ} \mathrm{C}$ and kept in the orbital shaker at $180 \mathrm{rpm}$. The initial $\mathrm{pH}$ of the solution was adjusted by addition of dilute aqueous solutions of $\mathrm{HCl}$ or $\mathrm{NaOH}(0.1 \mathrm{M})$. The samples were collected at definite intervals, filtered and analyzed spectophometerically for remaining concentration. For SAB studies 2,4-DCP was performed in $500 \mathrm{ml}$ cotton-plugged flasks containing $150 \mathrm{ml}$ of BSM with $20 \mathrm{ml}$ inoculum of acclimatized Pseudomonas putida with 2,4-DCP, having biomass concentration $32.50 \mathrm{mg} \mathrm{l}^{-1}$. Aliquots of 
$40 \mathrm{ml}$ from stock solutions of 2,4-DCP and adsorbent dose (1-12 $\left.\mathrm{g}^{-1}\right)$ was added to the reaction mixture and agitated in orbital shaker at constant speed of $180 \mathrm{rpm}$. Initial concentration of 2,4-DCP was varied between 100 to $1000 \mathrm{mg} \mathrm{l}^{-1}$. The $\mathrm{pH}$ and temperature ranges were from 2 to 9 and $25^{\circ} \mathrm{C}$ to $38{ }^{\circ} \mathrm{C}$, respectively. Samples were collected at definite intervals of time. All the collected samples were centrifuged at $10,000 \mathrm{rpm}$ for $15 \mathrm{~min}$. The supernatant was separated and analyzed spectrophotometrically at suitable wavelength. The percentage removal of adsorbate was calculated using the following relationship eq.(1),

Removal (\%) $=\frac{\mathrm{C}_{\mathrm{o}}-\mathrm{C}_{\mathrm{t}}}{\mathrm{C}_{\mathrm{o}}} \times 100$

where $C_{o}\left(\mathrm{mg} \mathrm{l}^{-1}\right)$ is the initial adsorbate concentration and $C_{t}$ is a concentration at time t. The isotherms were determined by analyzing adsorptive uptake of the 2,4-DCP from aqueous solution at distinct time intervals.

\section{Results and discussion}

\subsection{Adsorbent dose}

The percentage removal of 2,4 -DCP with adsorbent dose range 1 to $12 \mathrm{~g} \mathrm{I}^{-1}$ for adsorption and SAB is shown in fig 1 . The removal of 2,4-DCP was 86 and $91 \%$ for adsorption and SAB respectively as mentioned in Table 1.

Table 1. Effect of adsorbent dose on 2,4-DCP removal onto MSAC

\begin{tabular}{ccccc}
\hline & \multicolumn{2}{c}{ Adsorption } & \multicolumn{2}{c}{ SAB } \\
\hline $\begin{array}{c}\text { Adsorbent } \\
\text { dose } \mathbf{( g )}\end{array}$ & \%Removal & $\begin{array}{c}\text { Amount adsorbed/g of } \\
\text { adsorbent }\left(\mathbf{m g ~ g}^{-1}\right)\end{array}$ & \%Removal & $\begin{array}{c}\text { Amount adsorbed/g of } \\
\text { adsorbent }\left(\mathbf{m g ~ g}^{-1}\right)\end{array}$ \\
\hline 1 & 52 & 208 & 65 & 260 \\
\hline 5 & 65 & 52 & 75 & 60 \\
\hline 7 & 72 & 42.2 & 88 & 50.8 \\
\hline 10 & 86 & 34.4 & 91 & 34 \\
\hline 12 & 86.2 & 32.4 & 91.5 & 30.7 \\
\hline
\end{tabular}

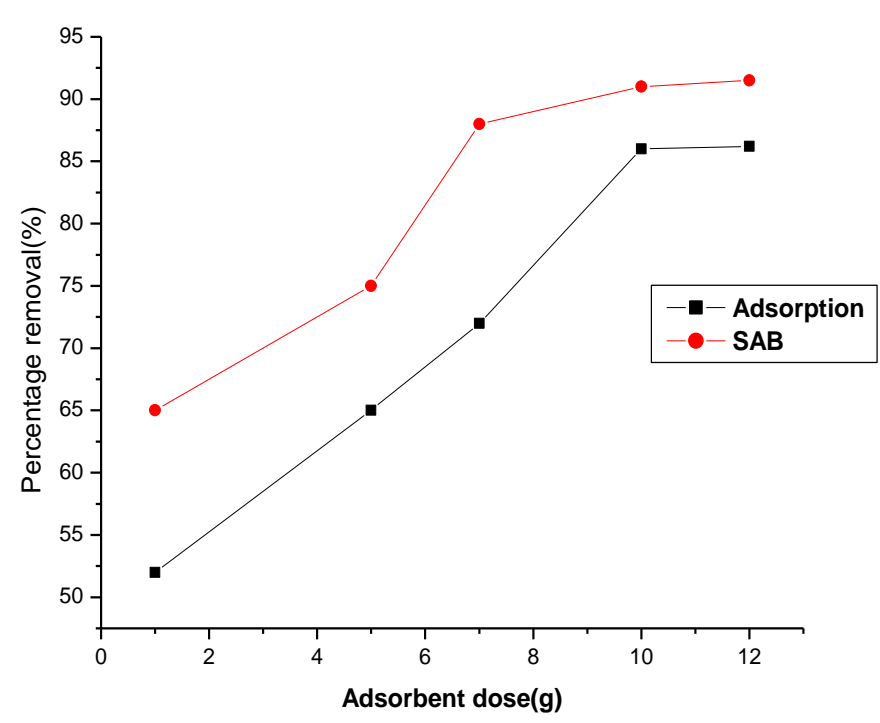

Figure1. Effect of adsorbent dose on removal of 2,4-DCP onto MSAC (At initial conc. $400 \mathrm{mg} \mathrm{l}^{-1}$ and $\mathrm{pH}$ 7) 
From fig.1 it is evident that the percent removal of 2,4-dicholrophenol reaches its constant value at the dose of around $10 \mathrm{~g} \mathrm{I}^{-1}$. In case of SAB the difference between the percent removal of SAB and adsorption is lower at the starting of the experiment (up to around one hour) but gradually increases and then remains constant. From the above observation it seems that for SAB, the adsorption dominates at the initial stage and bio-sorption dominates after reaching adsorption equilibrium. This agrees the mechanism of bio-filtration (Chaudhury et al., 2003) where bio-layer is formed followed by degradation of compounds.

\subsection{Effect of $\mathrm{pH}$}

In this experiment the percent removal for $\mathrm{SAB}$ was maximum at $\mathrm{pH} 6$. Figures 2 and 3 show percentage removal of 2,4-DCP at different $\mathrm{pH}$ by adsorption and $\mathrm{SAB}$, respectively.

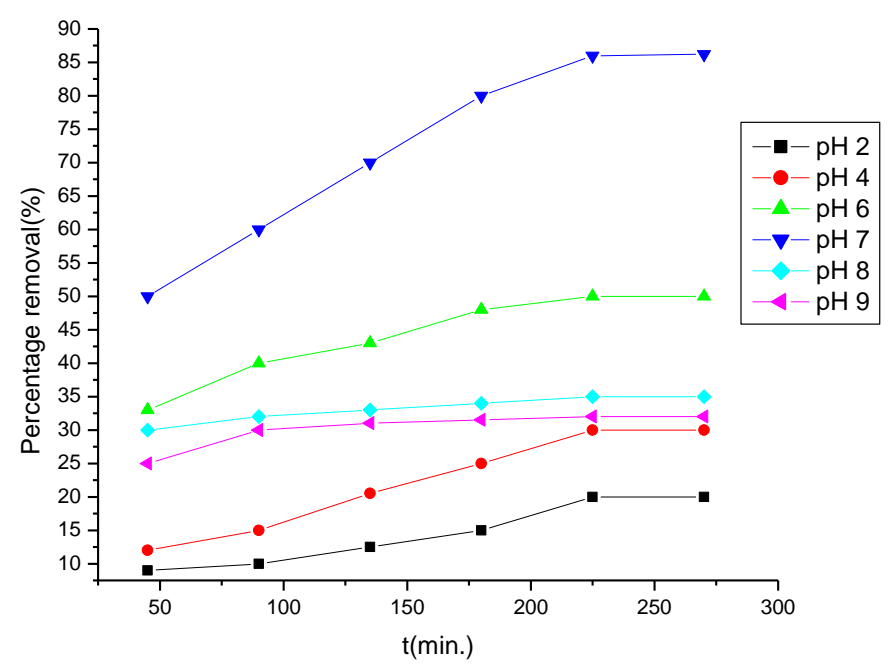

Figure 2. Effect of $\mathrm{pH}$ on removal of 2,4-DCP onto MSAC (Adsorption study) (At initial conc. $400 \mathrm{mg} \mathrm{l}^{-1}$ and adsorbent dose $10 \mathrm{~g} \mathrm{I}^{-1}$ )

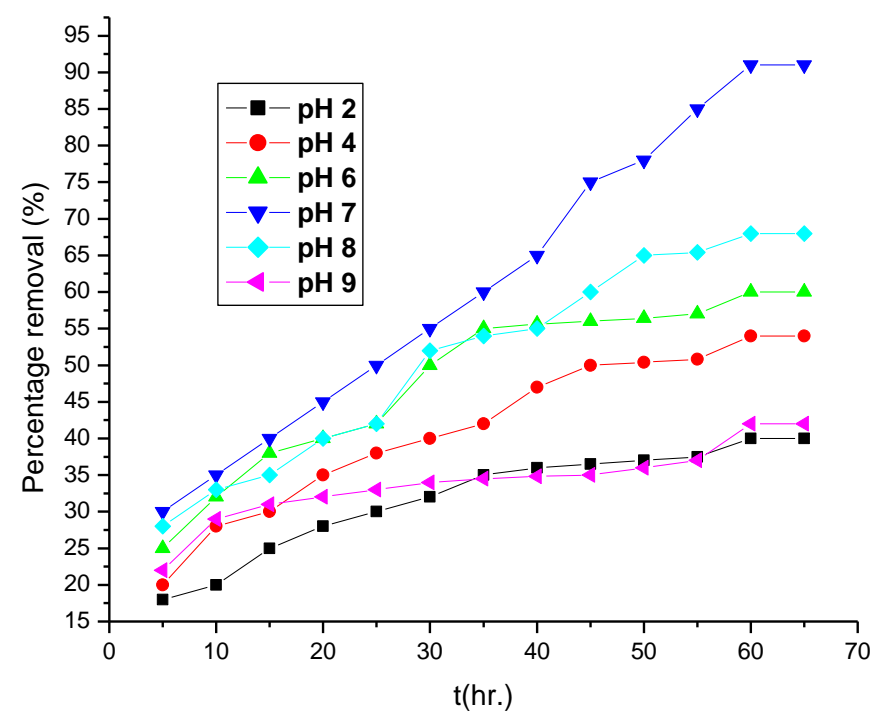

Figure 3. Effect of $\mathrm{pH}$ on removal of 2,4-DCP onto MSAC (SAB study) (At initial conc. $400 \mathrm{mg} \mathrm{l}^{-1}$ and adsorbent dose $10 \mathrm{~g} \mathrm{I}^{-1}$ ) 
The amount adsorbed of 2,4-DCP by MSAC varies $\mathrm{pH} 2$ to 9 as shown in Table 2. This observation agrees the fact that at near to neutral $\mathrm{pH}$ the specified microbes achieve maximum efficiency. The $\mathrm{pH}$ range 2 to 9 was chosen to study the effect of $\mathrm{pH}$ on the percent removal for SAB as well as adsorption studies. As the $\mathrm{pH}$ increased, overall surface charge on the cells became negative and sorption decreased.

Table2. Effect of $\mathrm{pH}$ on 2,4-DCP removal onto MSAC

\begin{tabular}{ccccc}
\hline \multicolumn{2}{c}{ Adsorption } & \multicolumn{2}{c}{ SAB } \\
\hline $\mathbf{p H}$ & \%Removal & $\begin{array}{c}\text { Amount adsorbed/ } \\
\left.\text { g of adsorbent(mg g } \mathbf{~}^{-1}\right)\end{array}$ & \%Removal & $\begin{array}{c}\text { Amount adsorbed/ } \\
\text { g of adsorbent }\left(\mathbf{m g ~ g}^{-1}\right)\end{array}$ \\
\hline 2 & 20 & 8 & 40 & 16 \\
\hline 4 & 30 & 12 & 54 & 21.6 \\
\hline 6 & 50 & 20 & 60 & 24 \\
\hline 7 & 86 & 34.4 & 91 & 27.2 \\
\hline 8 & 35 & 14 & 68 & 16.8 \\
\hline 9 & 32 & 12.8 & 42 & \\
\hline
\end{tabular}

Whereas the reduction in adsorption capacity are noticed at $\mathrm{pH}$ 9. The amount of phenol adsorption are high at $\mathrm{pH} 6$ on the other hand, the steep reduction in adsorption uptake capacity are found beyond $\mathrm{pH}$ 6 , due to ionization of adsorbate molecules and the electrostatic repulsion between the surface charge of MSAC and phenolic anions (Hameed, 2009).

\subsection{Effect of contact time}

For study of effect of contact time, 2,4-DCP concentration range $100-1000 \mathrm{mg} \mathrm{l}^{-1}$ at optimum pH 6 and dose $10 \mathrm{~g} \mathrm{I}^{-1}$ were taken for $65 \mathrm{hr}$ for SAB study where as for adsorption study $270 \mathrm{~min}$. The plot of 2,4-DCP concentration vs. time for adsorbent were shown in fig. 4 and 5 . The fig. 4 shows that removal rate of 2,4-DCP is found to be very rapid during the initial period of $30 \mathrm{~min}$. and then slows down. No significant change in the elimination of 2,4-DCP is observed after equilibrium time (Table 3 ). It can be seen from fig. 5 that the percent removal of SAB is not as much in the initial stage of experiment but it gets a rise after certain hrs and reached its optimum value at a particular point of time. These findings correlate with the study of Chaudhury et al., (2003) where a bio-layer has been formed due to the degradation of compounds and termed as the bio-filtration mechanism.

Table 3. Effect of contact time on removal of 2,4-DCP onto MSAC

\begin{tabular}{|c|c|c|c|c|c|}
\hline \multicolumn{3}{|c|}{ Adsorption } & \multicolumn{3}{|c|}{ SAB } \\
\hline $\begin{array}{c}\text { Contact } \\
\text { time(min.) }\end{array}$ & \%Removal & $\begin{array}{c}\text { Amount adsorbed/ } \\
\mathrm{g} \text { of adsorbent }\left(\mathrm{mg} \mathrm{g}^{-1}\right)\end{array}$ & $\begin{array}{l}\text { Contact } \\
\text { time(hr.) }\end{array}$ & \%Removal & $\begin{array}{c}\text { Amount adsorbed/ } \\
\mathrm{g} \text { of adsorbent }\left(\mathrm{mg} \mathrm{g}^{-1}\right)\end{array}$ \\
\hline 45 & 50 & 20 & 5 & 30 & 12 \\
\hline 90 & 55 & 23.2 & 10 & 35 & 14 \\
\hline 135 & 60 & 24 & 15 & 40 & 16 \\
\hline 180 & 75 & 30 & 20 & 42 & 16.8 \\
\hline 225 & 86 & 34.4 & 25 & 45 & 18 \\
\hline \multirow[t]{8}{*}{270} & 86 & 34.4 & 30 & 55 & 22 \\
\hline & & & 35 & 58 & 23.2 \\
\hline & & & 40 & 60 & 24 \\
\hline & & & 45 & 70 & 28 \\
\hline & & & 50 & 73 & 29.2 \\
\hline & & & 55 & 75 & 30.4 \\
\hline & & & 60 & 91 & 35 \\
\hline & & & 65 & 91 & 35 \\
\hline
\end{tabular}




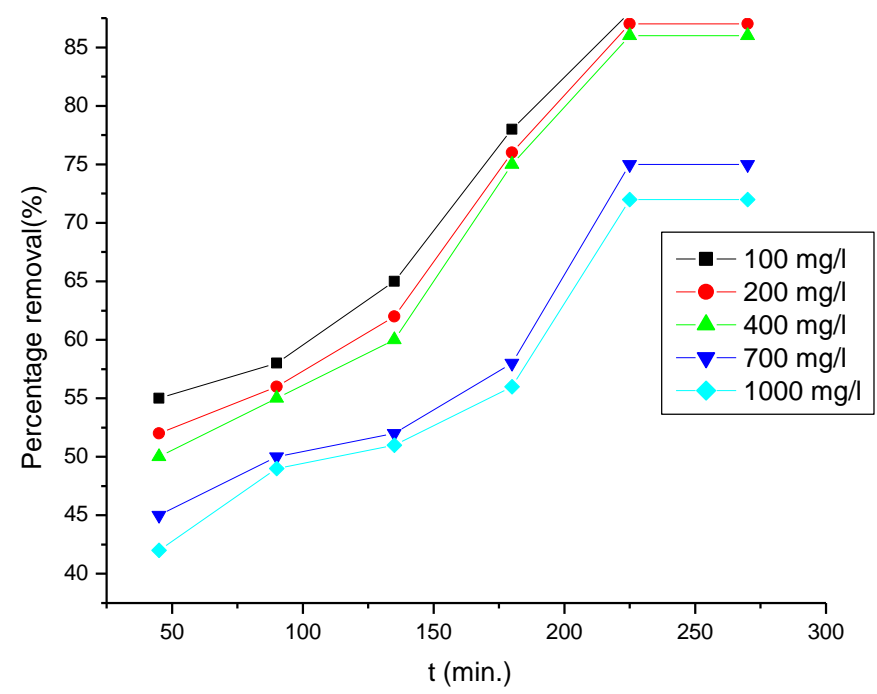

Figure 4. Effect of contact time on removal of 2,4-DCP onto MSAC (Adsorption study) (At adsorbent dose $10 \mathrm{gl}^{-1}$ and $\mathrm{pH} 7$ )

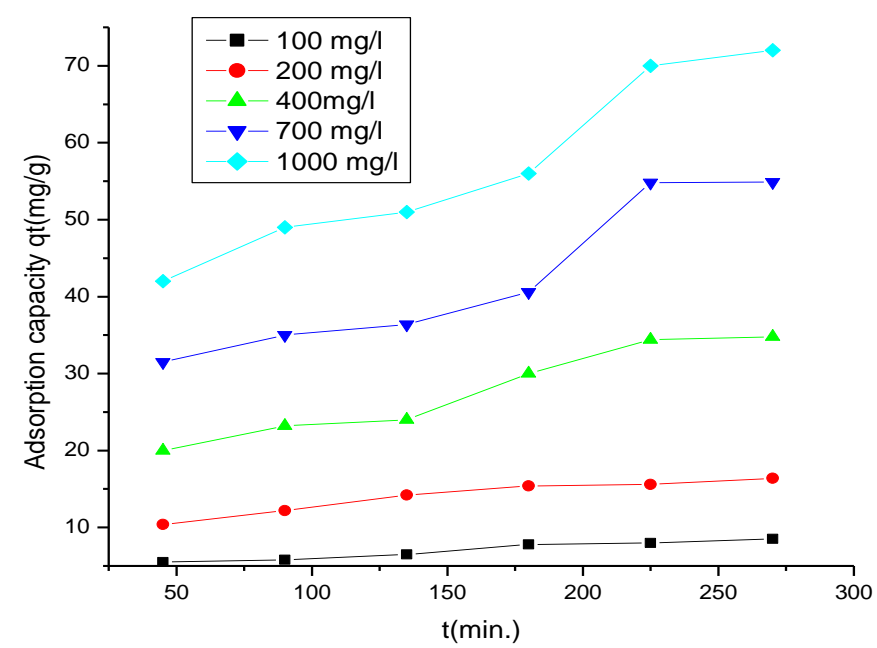

Figure 5. Effect of contact time on removal of 2,4-DCP onto MSAC (SAB study) (At adsorbent dose $10 \mathrm{~g} \mathrm{I}^{-1}$ and $\mathrm{pH}$ 7)

\subsection{Effect of initial 2,4-DCP concentration}

From fig. 6 and 7 it could be seen that the amount of 2,4-DCP adsorbed per unit mass of adsorbent increased with increase in initial concentration until equilibrium was reached at about definite time.

Table 4 show that percent removal of 2,4-DCP decreased with the increase in initial concentration. 


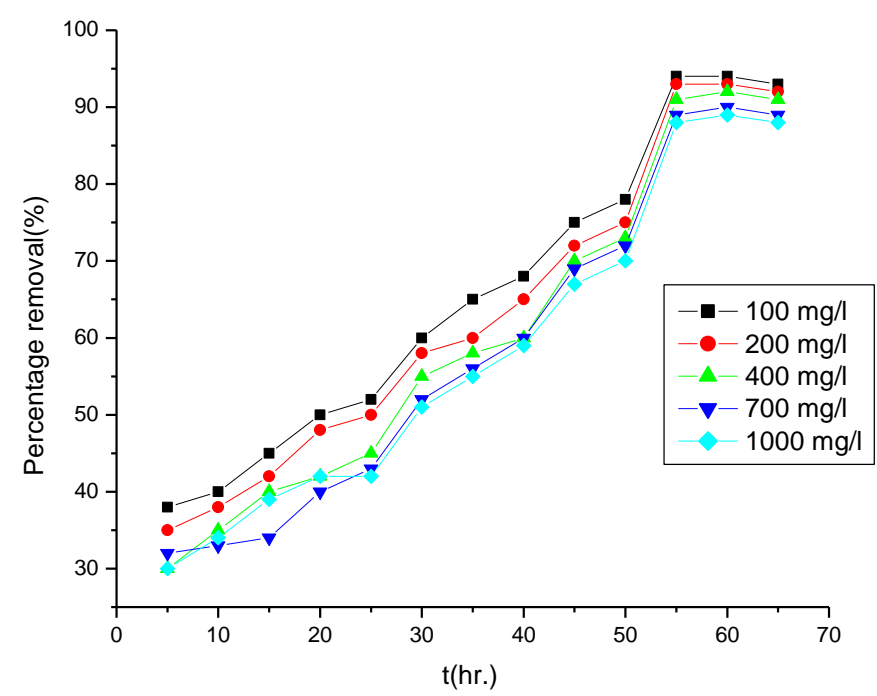

Figure 6. Effect of initial concentration on removal of 2,4-DCP onto MSAC (Adsorption study) (At adsorbent dose $10 \mathrm{gl}^{-1}$ and $\mathrm{pH}$ 7)

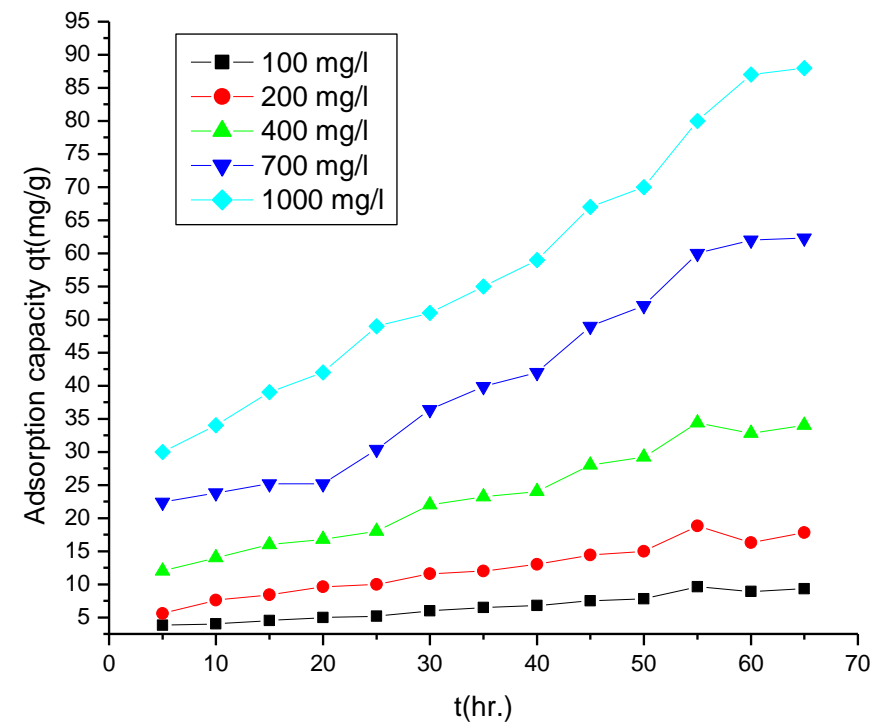

Figure 7. Effect of initial concentration on removal of 2,4-DCP onto MSAC(SAB study) (At adsorbent dose $10 \mathrm{gl}^{-1}$ and $\mathrm{pH}$ 7)

Table 4. Effect of initial concentration on removal of 2,4-DCP onto MSAC

\begin{tabular}{ccccc}
\hline & Adsorption & & SAB \\
\hline $\begin{array}{c}\text { Initial concentration } \\
\text { of 2,4-DCP }\left(\mathbf{~ m ~ ~}^{-1}\right)\end{array}$ & \%Removal & $\begin{array}{c}\text { Amount adsorbed/ } \\
\text { g of adsorbent }\left(\mathbf{m g ~ g}^{-1}\right)\end{array}$ & \%Removal & $\begin{array}{c}\text { Amount adsorbed/ } \\
\text { g of adsorbent }\left(\mathbf{m g ~ g}^{-1}\right)\end{array}$ \\
\hline 100 & 85 & 8.5 & 93 & 9.3 \\
\hline 200 & 82 & 16.4 & 92 & 17.8 \\
\hline 400 & 86 & 34.4 & 91 & 34 \\
\hline 700 & 75 & 54.9 & 89 & 62.3 \\
\hline 1000 & 72 & 72 & 88 & 88 \\
\hline
\end{tabular}




\subsection{Effect of temperature}

The fig. 8 and 9 show that with the increase in temperature removal of 2,4-DCP was increased. Table 5 shows maximum removal of $2,4-\mathrm{DCP}$ at $32{ }^{\circ} \mathrm{C}$ temperature, after that only a slight difference are seen for percentage removal. This is basically due to the fact that the diffusion process is an endothermic process (Weber, 1972). With an increase in temperature, the mobility of the phenolate ions increases and retarding forces acting on the diffusing ions decrease, thereby increasing the sorptive capacity of adsorbent. The increase in 2,4-DCP sorption capacity of the carbonaceous adsorbent with the increase in temperature has also been reported by other investigators (Banat et al., 2004, Vijayalakshmi et al., 1998).

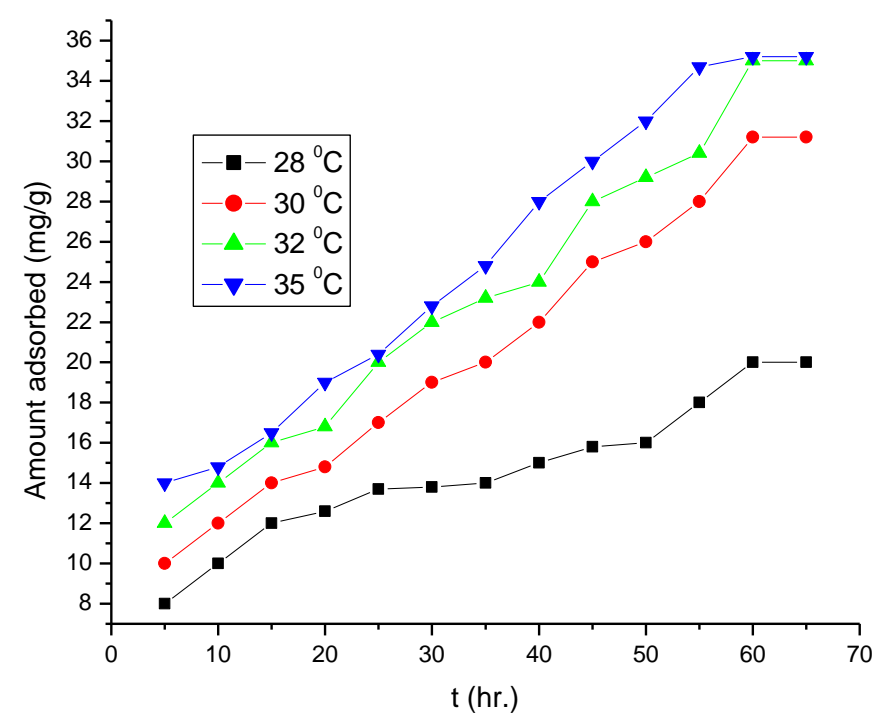

Figure 8. Effect of temperature on removal of 2,4-DCP onto MSAC (SAB study) (At $\mathrm{pH} 7$, adsorbent dose $10 \mathrm{~g} \mathrm{I}^{-1}$, initial conc. $400 \mathrm{mg} \mathrm{I}^{-1}$ )

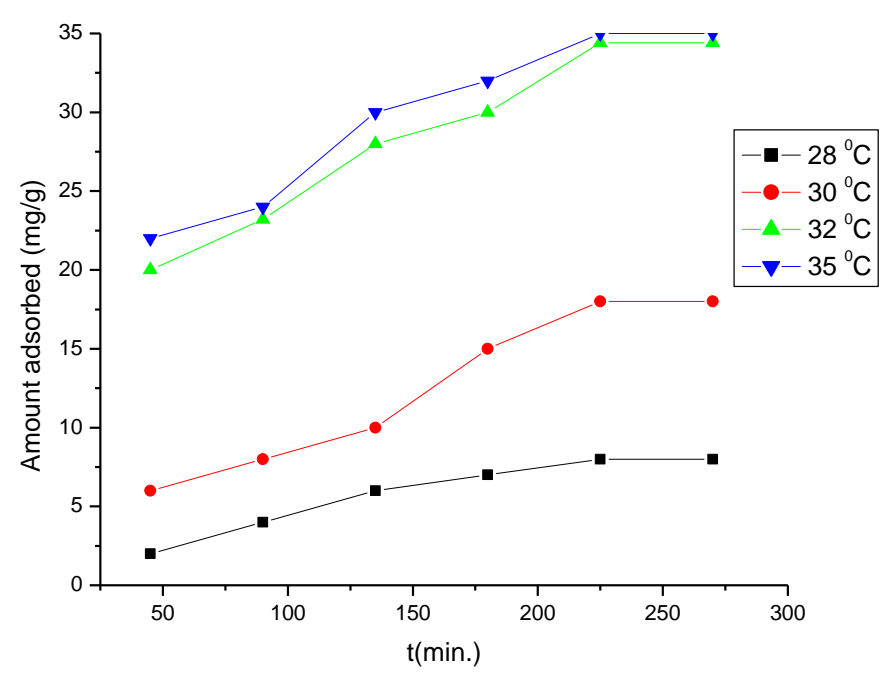

Figure 9. Effect of temperature on removal of 2,4-DCP onto MSAC (Adsorption study)(At pH 7, adsorbent dose $10 \mathrm{gl}^{-1}$, initial conc. $400 \mathrm{mg} \mathrm{I}^{-1}$ ) 
Table 5. Effect of temperature on removal of 2,4-DCP onto MSAC

\begin{tabular}{ccccc}
\hline & \multicolumn{2}{c}{ Adsorption } & \multicolumn{2}{c}{ SAB } \\
\hline $\begin{array}{c}\text { Temperature } \\
\left({ }^{\circ} \mathbf{C}\right)\end{array}$ & \%Removal & $\begin{array}{c}\text { Amount adsorbed/ } \\
\text { g of adsorbent }\left(\mathbf{m g ~ g}^{-1}\right)\end{array}$ & \%Removal & $\begin{array}{c}\text { Amount adsorbed/ } \\
\text { g of adsorbent }\left(\mathbf{m g ~ g}^{-1}\right)\end{array}$ \\
\hline 28 & 20 & 8 & 50 & 20 \\
\hline 30 & 45 & 18 & 78 & 31.2 \\
\hline 32 & 86 & 34.4 & 91 & 35 \\
\hline 35 & 86.2 & 34.6 & 91.5 & 35.2 \\
\hline
\end{tabular}

\section{Adsorption study}

The adsorption isotherms are important to describe the sorbate-adsorbent interaction. The isotherm data were analyzed by fitting them into Langmuir and Freundlich isotherm to find out the suitable model. The Langmuir eq.(2) is represented in the linear form as follows:

$\frac{\mathrm{C}_{e}}{\mathrm{q}_{\mathrm{e}}}=\frac{1}{\mathrm{~K}_{\mathrm{L}} \mathrm{Q}_{\mathrm{m}}}+\frac{\mathrm{C}_{\mathrm{e}}}{\mathrm{Q}_{\mathrm{m}}}$

where $\mathrm{K}_{\mathrm{L}}$ is Langmuir adsorption constant $\left(\mathrm{mg}^{-1}\right), \mathrm{Q}_{\mathrm{m}}$ is the theoretical maximum adsorption capacity $\left(\mathrm{mg} \mathrm{g}^{-1}\right)$, Ce is equilibrium liquid phase concentration $\left(\mathrm{mg} \mathrm{l}^{-1}\right), \mathrm{q}_{\mathrm{e}}$ is sorption capacities at equilibrium $\left(\mathrm{mg} \mathrm{g}^{-1}\right)$.

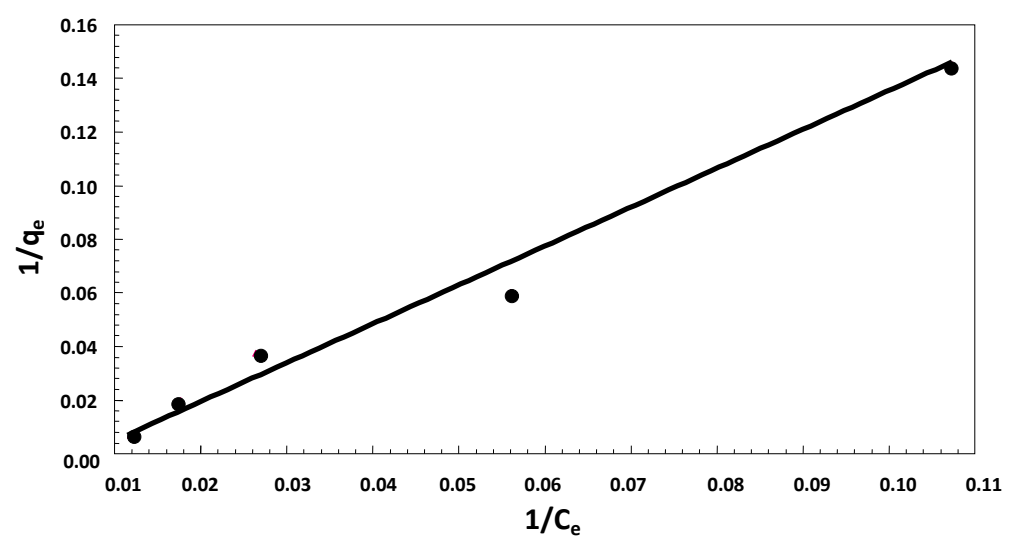

Figure 10. Langmuir isotherm for removal of 2,4-DCP onto MSAC (SAB study) (At $\mathrm{pH} 7$ and adsorbent dose $10 \mathrm{gl}^{-1}$ )

Figure 10 shows the Langmuir $\left(1 / C_{e}\right.$ vs.1/q $)$ plot of 2,4-DCP for SAB onto MSAC, which are found to be linear over the whole concentration range. The $Q_{m}$ is the theoretical maximum adsorption capacity 39.2 and $28.5 \mathrm{mg} \mathrm{g}^{-1}$ and the correlation coefficient $\left(R^{2}\right)$ are extremely high 0.998 and $0.985(\mathrm{SAB}$ and adsorption, respectively) as shown in Table 6 . The separation factor $\left(R_{L}\right)$ which is a measure of adsorption favorability, $R_{\mathrm{L}}$ values are in between 0 and 1 , thus validating a favorable adsorption process (Table 6).

The fitness of the Langmuir isotherm indicated the formation of monolayer coverage of the sorbate on the outer surface of the adsorbent. The linear Freundlich isotherm is expressed as eq. (3):

$\log q_{e}=\log K_{f}+\frac{1}{n} \log C_{e}$ 
where $K_{f}$ is Freundlich constant and $1 / n$ is Heterogeneity factor. Figures 11 shows that linear plot $\left(\log q_{e}\right.$ vs. $\log C_{e}$ ) of 2,4-DCP for SAB onto MSAC also follows freundlich isotherm.

Table 6. Constant values of adsorption isotherms for 2,4-DCP onto MSAC

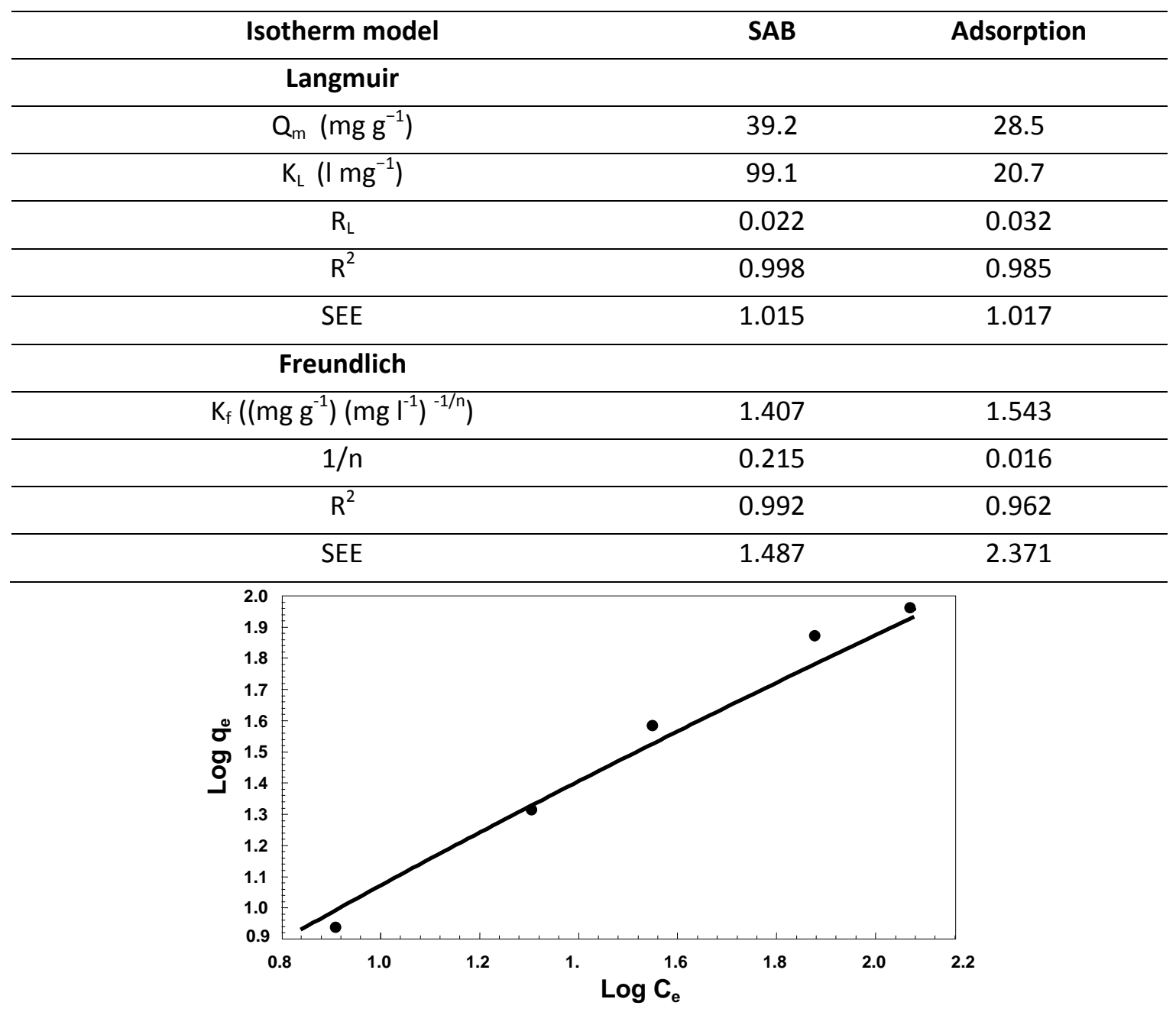

Figure 11. Freundlich isotherm for removal of 2,4-DCP onto MSAC (SAB study) (At $\mathrm{pH} 7$ and adsorbent dose $10 \mathrm{~g}^{-1}$ )

The freundlich constant value, $1 / \mathrm{n}(0.21$ and 0.16$)$ and correlation coefficient $\left(R^{2}\right) 0.992$ and 0.962 (SAB and adsorption, respectively) were reported in Table 6 . The less value of $K_{f}$ in case of $S A B$ indicates adsorption capacity of the adsorbent and higher values of $1 / \mathrm{n}$ (shift towards 1.0 ) indicates more adsorption intensity. The values of Langmuir and Freundlich isotherm constant and correlation coefficient $\left(R^{2}\right)$ for adsorption and SAB of 2,4-DCP are given in Table 6. The correlation coefficient for Langmuir isotherm are greater than those of Freundlich isotherm which confirms that Langmuir isotherm is better fit for the description of adsorption process.

\section{SEM micrographs}

The morphologies of MSAC after adsorption and SAB of 2,4-DCP removal were examined under scanning electron microscope. The SEM micrographs of MSAC are shown in fig. 12 and 13. The fig. 12 have linear type of fibers with holes which filled with 2,4-DCP after their adsorption. Figure 13 shows the 
development of micro-organisms inside the voids of activated carbon and cover the surface of MSAC by simultaneous adsorption and biodegradation of 2,4-DCP.

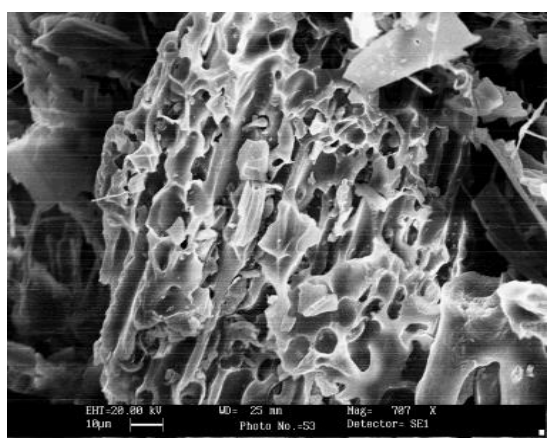

Figure 12. SEM Micrograph of MSAC after Adsorption of 2,4-DCP

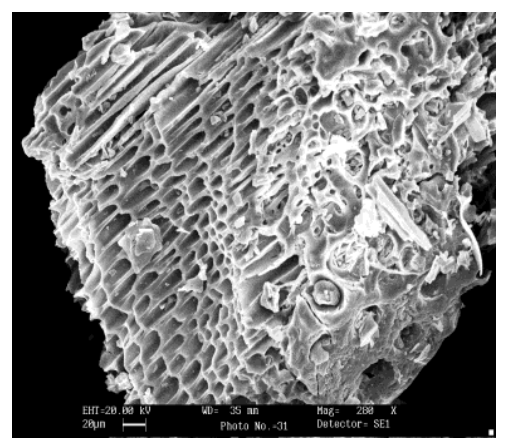

Figure 13. SEM Micrograph of MSAC after SAB of 2,4-DCP

\section{Conclusions}

1. Under the experimental study the optimum condition i.e. adsorbent dose $10 \mathrm{gl}^{-1}, \mathrm{pH} 6$ and $32^{\circ} \mathrm{C}$ temperature the 2,4-DCP removal efficiency of SAB (91\%) is more than that of adsorption(86\%).

2. The theoretical models verify the practically optimized parameters for the removal of the 2,4-DCP.

3. Langmuir isotherm is better fit than the Freundlich isotherm to explain the adsorption. The fitness of Langmuir's model indicated the formation of monolayer coverage of the sorbate on the outer surface of the adsorbent.

4. The results indicated that the MSAC with a support matrix of pseudomonas putida MTCC1194 as adsorbent is capable for the removal of 2,4-DCP with high affinity and capacity and use as a low cost adsorbent.

5. MSAC is an inexpensive, indigenous and easily available in large quantity and its use as sorbent would significantly lower the cost of wastewater treatment and in near future also tried for other toxic compounds removal.

\section{References}

Agarry S.E. and Owabor C.N. (2005), Utilization of rubber fruit pericarp - activated carbon for abattoir waste water treatment and absorption of iron (III) ions form aqueous solution, J. Sci. Technol. Res., 4(2), $49-54$.

Agarry S.E. and Solomon B.O. (2008), Inhibition kinetics of phenol degradation by Pseudomonas aeruginosa from continuous culture and washout data, Bioremediation J., 12(1),12-20.

Ahmedna M.,Marshall W.E. and Rao R.M.(2000), Production of granular activated carbons from select agricultural by-products and evaluation of their physical, chemical and adsorption properties, Bioresource Technology, 71(2),113-123.

Annadurai A., Ling L.Y. and Le J.F. (2007), Biodegradation of phenol by Pseudomonas pictorum on immobilized with chitin, Afr. J. Biotechnol., 6(3), 296-303.

Annadurai G., Juang R.S. and Lee D.J. (2002), Adsorption of heavy metal from water using banana and orange peels, Water Sci.Technol., 47, 185-190.

Banat F., Sameer A.A. and Leema A.M. (2004),Utilization of raw and activated date pits for removal of phenol from aqueous solutions, Chem. Eng. Technol., 27, 80-86.

Chaudhury D.S., Vigneswaran S., Ngo H.H., Shim W.G. and Moon H. (2003), Biofilter in water and waste water treatment, Korean J. of Chem. Eng., 20(6), 1054-1065.

Chen B., Yuana M. and Liu H. (2011), Removal of polycyclic aromatic hydrocarbons from aqueous solution using plant residue materials as a biosorbent, J. Hazard Mater., 188, 436-442. 
Devipriya S.P. and Yesodharan S. (2010), Photo catalytic degradation of phenol in water using $\mathrm{TiO}_{2}$ and $\mathrm{ZnO}$, J. Environ. Biol., 31, 247-249.

Hameed B.H. (2009), Spent tea leaves: A new non-conventional and low-cost adsorbent for removal of basic dye from aqueous solution, J. Hazard. Mater., 161, 253-259.

Madhava S., Krishnan M.K., Sameena Y., Selvam K., Rasappan K. and Pattabhi S. (2006), Removal of Rhodamine dye from aqueous solution using gulmohar tree fruit activated carbon, Ecology Environment and Conservation, 12(2), 217-222.

Mahadevaswamy M., Mall I.D., Prasad B. and Mishra I.M. (1997), Removal of phenol by adsorption on coal fly ash and activated carbon, Pollution research, 16(3), 170-175.

Mondal P. and Balomajumder C. (2007), Treatment of resorcinol and phenol bearing waste water by simultaneous adsorption biodegradation (SAB): optimization of process parameters, International Journal of Chemical Reactor Engineering, 5, 51-58.

Parida K.M. and Prahan A.C. (2010), Fe/Meso-Al203: An efficient photo-fenton catalyst for the adsorptive degradation of phenol, Ind. Eng. Chem. Res., 49, 8310-8318.

Popuri S.R., Jammala A., Reddy K.V.N. and Abburi K. (2007), Biosorption of hexavalent chromium using tamarind (Tamarinddus indica) fruit shell - a comparative study, Electronic J. Biotechnol., 3, 358-367.

Reddad Z., Gerente C., Andres Y. and Lecloirec P. (2002), Adsorption of several metal ions onto a low cost biosorbent: Kinetic and equilibrium studies, Environ. Sci. Technol., 36, 2067-2073.

Vijayalakshmi P.R., Raksh V.J. and Thirumaleswara S.G.B. (1998), Adsorption of phenol, cresol isomers and benzyl alcohol from aqueous solution on activated carbon at 278, 298 and 323 K., J. Chem. Technol. Biotechnol., 71, 173-179.

Wang C.C., Lee C.M. and Kuan C.H. (2000), Removal of 2,4-dichlorophenol by suspended and immobilized Bacillus insolitus, Chemosphere, 41, 447-452.

Weber W.J. Jr. (1972), Physicochemical Processes for Water Quality Control, Wiley Interscience, New York.

Zhao G.H., Li Y.F., Liu X.X. and Liu X.L. (2010), Preparation of capsules containing 1-nonanol for rapidly removing high concentration phenol from aqueous solution, J. Hazard Mater., 175, 715 -725. 